\title{
Beyond the Socratic Method: Exploring Alternative Theories in Legal Education
}

\author{
Kenneth I. Granle Jr. MA, JD ${ }^{1 *}$ \\ ${ }^{1}$ Adjunct Professor of Business Law Roosevelt University 430 S. Michigan Ave, Chicago, IL 60605 USA
}

\author{
DOI: $10.36348 /$ sijlcj.2022.v05i01.004 | Received: 05.12.2021 | Accepted: 06.01.2022 | Published: 24.01 .2022 \\ *Corresponding author: Kenneth I. Granle Jr. MA, JD \\ Adjunct Professor of Business Law Roosevelt University 430 S. Michigan Ave, Chicago, IL 60605 USA
}

\section{Abstract}

Legal education has changed very little over the last century. At the same time, there have been significant advances in the field of education leading to several theories. The following will examine the five leading theories of education: connectivism, humanism, constructivism, cognitivism, and behaviorism. Each of these will be evaluated next to the Socratic Method, which is the primary method employed by law school instructors. Specific examples of how some of these theories have surfaced in law school and how the Socratic Method embodies other theories will be noted. The effect of technology on law school instruction will also be addressed. The overall goal of this article is to reveal how these theories can be utilized in the law school setting to produce highly competent graduates who will improve the efficacy of the field as a whole. Anecdotal example from North American and African law schools will underscore the notions put forth in this article.

Keywords: Law school, legal instruction, Socratic Method, education theories.

Copyright ( 92022 The Author(s): This is an open-access article distributed under the terms of the Creative Commons Attribution 4.0 International License (CC BY-NC 4.0) which permits unrestricted use, distribution, and reproduction in any medium for non-commercial use provided the original author and source are credited.

\section{INTRODUCTION}

The curriculum in African and North American law schools has changed very little over the last century. However, as other fields have begun to reevaluate their educational policies, there has been a movement to overhaul traditional practices to make legal education more approachable and suitable for the modern needs of the profession (Kleeger, 2019). While this is a bit of an extreme stance, legal instruction does deserve some review, as there is room for improvement. The Socratic Method has become synonymous with law school, but this is neither the only way nor the best way to teach every aspect of law. Modern theories of education reveal that there are flaws to this method, especially when student interest and engagement are concerned (Donahoe \& Ross, 2020). By analyzing the most fundamental components of legal education, including basic theories of education, teaching and instruction can be greatly improved.

\section{METHODOLOGY}

The following will examine the five leading theories of education: connectivism, humanism, constructivism, cognitivism, and behaviorism. While these theories are normally discussed in analyses of children's education and development, their basic tenants can still be applied to adult and professional education. Each theory will be discussed in terms of its history and origin as well as its potential application to legal education. Though the coined terms for each of these theories only emerged in the past century, there is evidence to suggest that their approaches were employed well before that. Particular emphasis will be placed on weighing the benefits that accompany these approaches against any detriments that should be of concern to educators. As the practice of law often requires an attorney to disconnect from certain subject matter, it is obvious that certain aspects of the more emotionally involved theories of education would not be appropriate. Some focus will be given to any aspects of these theories that already appear in contemporary legal education through the use of the Socratic Method or other standard practices such as clinics and internships.

This analysis of the leading theories of education will draw from scholarship from around the world. Cited scholarship will include works by authors who are both legal professionals and educational experts. Both support and criticism of each theory will be utilized in an attempt to present an impartial 
Kenneth I. Granle., Sch Int J Law Crime Justice, Jan, 2022; 5(1): 22-29

summary. Understanding that legal systems differ across the globe and even within particular countries, focus will be on the very basics of legal education that are practically universal in every country. Following the prevue of this journal, sources from African lawyers and educators were sought to bring their perspective to the forefront. While there may be some references to religious law and tribal courts, the focus will be on education for a secular society. Some discussion of the differences in law school curricula will be included, but it is not the aim of this article to suggest that any such curriculum need to be completely redesigned. Rather, this analysis and discussion will illuminate how difference theories of education can be utilized in the law school classroom to boost understand of key concepts and ultimately produce better attorneys in practice.

\section{DISCUSSION \\ Behaviorism}

Changes in human behavior can be one of the easiest ways to measure growth and development in an individual. Some educational theorists even see education solely as the "process of changing behavior patterns of people" (Tyler, 1949, p. 5). The main idea behind the behaviorist theory of education is that we should focus on external factors that affect the behavior of our students and how we can alter those behaviors to reach certain educational goals. There is a significant focus on consequences, but little to no concern about an individual student's thought process (Ertmer \& Newby, 2013 , p. 51). This means that students can arrive at the correct conclusion, and therefore the correct action, through different lines of reasoning, but the instructor should only be concerned if a student comes to the wrong conclusion entirely.

Behaviorism as a theory can be divided into three different branches: methodological behaviorism, psychological behaviorism, and logical behaviorism (Garrison, 2018). The way that educators employ behaviorist rhetoric differs depending on the age group. In younger students, learning of this kind can be seen as a process of active engagement (Wilson \& Peterson), which leads to the refinement of base skills. This can be seen through children learning to count, read, and write; the change in behavior is from not knowing how to do a task at all to having recognizable competency. As we progress to adult learners, behaviorism can be employed to reconsider our behavior towards certain topics. The numbers that with which students learned to count become abstract, infinite, and even irrational. Reading in a native language, something that is not soon forgotten, must be reconsidered as foreign tongues are introduced. Even the most basic behaviors in writing are challenged when learning cursive or calligraphy for the more courageous. While these examples are a bit attenuated, the overall concept of changing a behavior with little concern for intellectual pathway remains.
In the realm of legal education, there is a significant focus on the way that students think, and the logical paths they use to arrive to the right conclusion, as opposed to the manifestation of that thought process through their behavior. Some may even argue that behaviorism, among other educational theories, has no place in legal education (Boghossian, 2013). However, this is both a narrow view of law school and behaviorism itself. Successful lawyers understand the importance of finessing their behavior with clients, judges, witnesses, court staff, and other lawyers as both colleagues and opposing counsel. While emeritus professors may stress that these are skills to be learned on the job and that your time in class should focus solely on jurisprudence, the contemporary law school curriculum is designed to make students ready for a career as soon as they graduate. This includes behaving like a lawyer in a myriad of situations.

Critics of the use of behaviorism in legal education may cite its focus away from mental processes when much of law school is designed to promote a new type of thinking and reasoning. However, behaviorists understand that "behavior is seldom simply the result of mindless... connections" (Lefrançois, 2020, p. 215), yet we do not need to be overly concerned with thought process when we are seeking to change how a student acts. Similar criticism relies on the social justice implications that a behaviorist approach to legal education may have (Kaufman, 2017), which is again an oversimplification and generalization.

The behaviorist approach certainly cannot be used to teach every aspect of law, but it can be employed to teach many of the skills that graduates are now expected to know. Many law schools already use networking events and job shadowing events to introduce fledgling legal scholars to those who currently practice. Taking this a step further, professors could actually critique interactions of law students with attorneys and judges. An educational exercise without an assessment is not altogether pointless, but there exists proof that assessment can drive learning and boost engagement (Kohn). Taking these encounters from passive experiences to active and evaluated learning exercises would instill the fundamentals of behaviorism. It would also be prudent of schools to require students to partake in observed interactions with other groups of people that typically find themselves entangled in legal proceedings. When selecting participants for such interactions, it is important to take into account "the psychological needs and characteristics of students and their emerging and changing... identities" (Banks, p. 169). This could include law enforcement, juveniles, and homeless individuals.

It is apparent that some form of behaviorism already exists in most law school settings, though it is 
neither pervasive nor appropriate in every subject. Some refinement might extend the usefulness of behaviorist exercises with law students. What remains important is distinguishing between changes in behavior and changes in thought patterns, the latter of which is the true purpose of law school.

\section{Cognitivism}

Similar to the behaviorist viewpoint, cognitivism analyzes on an individual's response to experiences. However, the focus in not on how these experiences change behavior, but on how they affect the development of cognitive pathways. This include both conscious appreciation of one's thoughts as well as the resulting actions (Fox \& Riconscente, 2008). This type of learning involves a significant amount of reading and lecture-based instruction, which lends itself well to the general study of law.

One might even see the Socratic Method as the practical or active application of cognitivism or at least an exercise that fits within its purview. A central theme in cognitivist education is improvements through practice, generally with stimuli building on previous knowledge (Higueras-Herbada, de Paz, Travieso, Ibáñez-Gijón, \& Jacobs, 2019). The Socratic Method involves such stimuli in its professor-lead question and answer approach. Furthermore, when considering the writing exercises used in law school classrooms, we see that both the Socratic Method and cognitivism rely on a student's procedural knowledge (Al-Jarrah, Mansor, Talafhah, \& Al-Jarrah, 2018); not only are students required to explain what they know, the must explain how they arrived to that conclusion.

This sort of conscious understanding of one's own knowledge is not unique to cognitivism. However, this theory of education does seek to refine the concept and establish parameters for more effective education. In the law school setting, many examples of cognitivism are present. As was mentioned earlier, significant focus is placed on writing and lectures. In most US, British, and African law schools, this is the crux of instructional practices. There are very few assignments that rely on mere recitation of facts. Essentially, law school curriculum is "designed as to prepare students with professional competency (expertise and skill) in addition to master theoretical matters" (Endarto, Alam, \& Abadi, 2019, p. 1). Law students are rarely asked to remember facts or specific laws; it is their application of legal maxims and reliance on precedent that need to be tested.

In many African universities, the notion of Competence-Based Education (CBE) has taken hold and lead to some debate about its place in legal education. The idea behind $\mathrm{CBE}$ is that instructors should focus on general knowledge and the ability to use facts rather than the ability to recite or remember important facts themselves (Kouwenhoven, 2009).
While this may seem apropos in many disciplines, including legal studies, it has been met with some scrutiny. Much of the work of a lawyer is applying facts that they have been presented about a client's case. However, some knowledge of key facts in always necessary. In addition, licensing exams such as the Bar Exam in the United States do require specific knowledge of facts pertaining to many different areas of law. While CBE is certainly an effective approach that follows the tenants of cognitivism, its use should not be entirely void of fact-based education.

Another cognitivist approach to higher education that has emerged in some law schools, including many in Ghana, Liberia, and Nigeria, is Theater-for Development (TfD) education. This approach focuses on lesson that is driven by both theory and practice in an attempt to emulate those currently working in a given field (Nyatuame, 2019). While this does have some correlation with behaviorism, which was previously discussed, and connectivism, which will be discussed at the end of this paper, its main underpinnings are in cognitivism.

Strategies such as CBD and TdF fit within the cognitivist ideology, and variations of them do appear in contemporary legal education. While they are not examples of the Socratic Method, which can be viewed as applied cognitivism, they are still effective ways of educating future lawyers. Similar to behaviorist approaches to legal education, some slight refinement would increase their effectiveness but an overall redesign of the curriculum is not necessary.

\section{Constructivism}

One of the most famous theories of education, constructivism, places much more emphasis on the role of the learner. A cornerstone of this approach is the belief that learners do not simply play a passive role in the classroom. Rather, learners construct their own knowledge through interactions with the surrounding environment (Adom, Yeboah, \& Ankrah , 2016). In addition, these learners are expected to reconstruct some of the knowledge they have already learned in order to form better connections that deepen their understanding. This can present myriad issues, especially for adult learners (Olivares \& Lemberger, 2002), but successful implementation has garnered success across disciplines (Motallebinejad, Hatami, \& Farda, 2019).

Considering the study of law, it is easy to see how constructivism fits into the already established educational practices. This is most prominent in early law school lessons where professor and students must work together to break some connections that they have made in order to reconstruct them in a more correct and lawyerly manner. For example, many students come to law school believing that morally right and wrong align with legal and illegal. This, of course, is not the case, 
Kenneth I. Granle., Sch Int J Law Crime Justice, Jan, 2022; 5(1): 22-29

and students must learn to abandon their preconceived notions in order to proceed with their studies and succeed in their program. This is particularly true when it comes to the study of criminal procedure, evidence, and estate law.

A particularly important part of the constructivist theory is active engagement by the student. Students are not meant to just sit back and absorb information that is presented to them; for actual learning to take place, the student must be an active participant. In as much, "The constructivist teacher must... provide activities which engage the mind... the learners" (Adom, Yeboah, \& Ankrah , p. 8). This cannot take place in a normal lecture hall setting. The use of the Socratic Method does boost student engagement, but only really for the student who is being questioned by the professor. The rest of the students are merely observing the process unless they voluntarily enter into the question and answer session.

Boosting engagement through simulations is one way that a law school instructor can ensure that all students are actively engaged in the learning process. Simulations allow students to not only learn from their experiences but also use their imaginations (Maharg, 2016). Imagination is not something that is often seen as useful in the law school setting. This may in fact be another downfall when it comes to reliance on the Socratic Method. When considering how creative modern lawyers need to be when it comes to deals and dispute resolution, an active imagination should be seen as an asset to lawyer and law students alike.

Successful constructionist rhetoric also requires a connection to emotions. This is quite contrary to most a law school teaching as students are taught to divorce themselves from emotion. The constructivist view is that "emotions are in fact an integral and inescapable part of the academic endeavor" (Emma, 2018, p. 11). The study of law cannot be the only discipline in which students are expected to divorce themselves from their emotions. Rather, it seems that it would be more prudent to explain to students how and when to employ emotions in to the practice of law. Judges, juries, and even opposing parties can easily be swayed by emotions. When working with victims of crimes, understanding emotions is essential. A working knowledge of emotions and their effect on legal outcomes can certainly boost a student's presence within a classroom (Corbin \& Bugden, 2018) and that can easily be transferred into the courtroom.

The constructivist approach, active learning by experience with present emotions and active imaginations, may not seem like it would fit easily into the law school setting, but the fact of the matter is that its application advances the goals of legal education on many fronts. Allowing students to use their imaginations, express their emotions, and take a more active role in their learning can help them better address the work of a lawyer. This should only be used to supplement tradition lectures, but its application can greatly improve student outcomes and success.

\section{Humanism}

While it holds many similarities to the other learning theories, humanism distinctly focuses on the individual as the subject of learning. Emphasis is shifted from what can be learned or experienced from a given situation to what a student actually learned. This can be seen as a form of self-actualization, and some theorists even like to acknowledge it as an awakening of knowledge and understanding that already existed inside the learner.

Obviously, the vast amount of human knowledge in law or other disciplines cannot lie dormant inside every person, but the ability to comprehend new information and synthesize it with prior knowledge certainly does. The humanist approach relies heavily on role modeling and other scenarios in which the learner gets to both observe and imitate others. The idea is not to show students what professionals in their prospective line of work do or what they know, but how it actually feels to be one of them.

Most law students love the opportunity to imitate real lawyers. However, a truly humanist approach requires the correct learning environment and cannot be completed in isolation (Javadi \& Tahmasbi, 2020). The traditional lecture hall of a law school setting may not be the best place for humanist lessons, but smaller group setting would both underscore the notions of the theory and ensure that students are not trying to pretend what it is like to be a lawyer entirely on their own. With the proper setting, students "learn more easily and quickly when analyzing the skills that matters to them" (Javadi \& Tahmasbi, p. 46). The driving force behind humanist approaches is keeping students interested, which certainly can be accomplished by appealing to their career aspirations.

Modern approaches to humanism, including its implementation in higher education and nontraditional fields, have found some challenges. Arguments abound concerning the impracticality of replacing traditional textbook education with experiential learning. Contemporary humanists stress the importance of being constructive rather than instrumental in applying humanism to curricula (Soudien, 2019). Current law school curricula are able to produce successful lawyers, but there is always room for improvement. The humanist approach should be seen as something that can be added to current lesson plans and not something that will replace currently successful practices.

One aspect of humanism that resonates throughout countries whose legal systems stem from the 
Kenneth I. Granle., Sch Int J Law Crime Justice, Jan, 2022; 5(1): 22-29

British tradition is its connection to postcolonial ideologies. In the wake of decolonization, many countries across Africa and Asia were left with governments and court systems that were very different from what they possessed prior to European influence and interference. Examining the consequences that colonial control and exploitation had on colonized people and their lands, it is understandable why acceptance of a legal system as prescribed by England or another European entity would meet some resistance. What was clearly not an equal exchange of ideas and resources (Northrup, 2013) lead to disparities that are still far from being ameliorated. A humanist approach to legal education may be a way to counteract this, even establishing an arena in which postcolonial issues can be discussed. (Noyes, 2002). By focusing on the experiences of being an attorney, along with a victim and an accused person, law students can bring a different perspective to the classroom.

Aside from what might be seen as roleplaying, a humanist approach to legal education can be achieved by using sources other than standard textbooks and case briefs. Supplementary material may illuminate ulterior motives, hidden fears, and unexpected consequences resulting from a criminal action or civil dispute. Assigning these to students allows them to go beyond universal reasoning to individual reasoning in their legal analysis. (Ramrathan, 2019) Too often in the legal realm, students and attorneys alike dehumanize legal issues; by rehumanizing rhetoric, the legal system can bring equity and compassion back to the courtroom.

\section{Connectivism}

The final educational theory that this article will discuss is connectivism. True to its namesake, the connectivist approach maintains many connections to other theories of education. In essences, it seeks to allow students to make connections from facts and concepts they already know to new information. Much of this relies upon what is known as situated cognition (Mattar, 2018) which emphasizes the importance of setting in the introduction of new information. Consequently, the introduction of new information in the wrong setting can prove detrimental in the connectivist approach. (Sahin, 2012). A law school classroom can be the right setting, but there are many more factors that need to be considered.

Much of the work that lawyers, law students, and legal scholars do can be seen as establishing connections. A robust network of like-minded individuals, people concerned with the study and practice of law in this situation, proves beneficial in connectivist rhetoric. (Al Dahdouh A. , 2019). When reviewing case precedence, attorneys attempt to compare or contrast their current situation to one that has already been decided by a court. Students in law school constantly build upon what they have already learned and need to connect ideas between subfields of law. An astute professor will realize that a simple concept, like establishing a prima face case or shifting burden of proof, will have been covered in introductory courses and that the class can connect to those lessons as students move forward with more difficult concepts. Problems can arise when students attempt to use inappropriate knowledge in an unrelated area of law, such as applying criminal standards to civil manners, which is one of the pitfalls of this approach to education.

Connectivism is a relatively young learning theory, only being popularized in the twenty-first century. Since then, it has gone through some shifts and changes as educators have sought to differentiate it from constructivism. One popular notion is the idea that connectivism "includes elements like emotions, recent experiences, beliefs, and the surrounding environment..." (Downes, 2020, p. 115). This would almost make the theory more like humanism or behaviorism, which suggests that connectivism is an amalgamation of the other four leading theories. Concerning emotions, it is important to understand that like inappropriate setting, negative emotions can trigger ineffective or inappropriate results. (Al Dahdouh A. A., 2020). Thus, keeping emotions under control, especially when addressing sensitive or disturbing subject matter during class, is essential to the connectivist ideology.

Technological advances have bolstered the support of connectivism as a learning theory in its young age. The internet and other online resources allow for seemingly limitless connections to be made between different sources of information. From an educational standpoint, this can be seen as both an asset (Sánchez Cabrero \& Costa Román, 2018) and a detriment (Kizito, 2016) to the learning environment. While the internet can break down barriers to information, there is a heightened difficulty in policing this information and verifying reliable sources. Particularly in the realm of law, where legal theory is subject to interpretation, an instructor may find it difficult to ensure that students are following a distinct line of reasoning when they have open access to contradictory opinions. While the point of legal education is to create an inquisitorial minds, some semblance of order must be established first as students learn legal maxims and the most basic of principles.

A successful example of the implementation of online resources in legal education with a connectivist approach can be seen in work being done by the University of South Africa College of law. This college has developed an online module for introducing students to the true nature of the criminal law system in South Africa. The module seeks to establish a "basic understanding of what shapes [the South African] legal system, the nature of South African law and the criminal justice system and how law and justice is applied and administered" (Ovens \& Jonker, 2014, p. 
Kenneth I. Granle., Sch Int J Law Crime Justice, Jan, 2022; 5(1): 22-29

2). By creating this online module, the law school was able to offer introductory legal education via distance learning and at the same time control the types of connections that students make as they explore the realm of criminal law in South Africa. Students can of course search for additional sources outside of the module, but the initial framework does provide for consistency in students' foundational understanding.

\section{CONCLUSION}

Each of the previously discussed theories of education has the potential to improve legal education. Certain theories can already be observed in the law school classroom and the Socratic Method itself is a manifestation of others, albeit unintentionally. Careful implementation of these methods and refinement of current practices will greatly benefit to overall experience of legal education for both law students and instructors.

Measuring a student's growth and development can often be achieved by observing changes in behavior. A behaviorist approach to instruction seeks to guide changes in behavior, with the focus being the end result rather than individualized thought processes. A narrow view of this theory may seem inappropriate for adult and legal education, but when broadly considered, its application does support much of the professional development needed for contemporary lawyers. Many law schools already employ a latent form of behaviorist rhetoric, but a more guided approach would lead to more success in both the classroom and courtroom.

A focus on cognitive pathways can also greatly improve law school instruction. The Socratic Method fits nicely within the purview of cognitivism, with its reliance on a student's procedural knowledge and problem-solving skills. Law schools across North America and Africa focus on the application of law rather than memorization of specific laws. Competent use of facts and a well-developed thought process are essential for success as a law student, both of which can be obtained through a cognitivist approach to legal education.

Students cannot sit idle in the classroom, especially if they want to prosper in a competitive field such as law. Constructivist rhetoric requires active participation, though students may need to deconstruct and reconstruct previously learned concepts. This is already an issues for many law students, especially when approaching the difference between legality and morality. Engagement through simulations is one way to boost student involvement and unearth students' creativity and emotions. However, it is important to establish boundaries for professional practice.

All too often, law dehumanizes people and their problems, which can be seen as a lasting effect of imperialism. A humanist approach to legal education not only rehumanizes the subject matter but can create lawyers who strive for equity in their profession. Imitating real lawyers, judges, police officers, and even victims allows students to experience what it is like to be part of the human factors of the court system. Of course, traditional lectures and textbooks cannot be replaced entirely by pretend activities, but adding them to the curriculum will both enhance students' interest and add another dimension to their understanding of the subject matter.

Connecting ideas proves essential in every discipline, and the field of law is no exception. Applying facts to law is most basic definition of the work of a lawyer. The connectivist theory of education, which draws upon the other four theories, views the classroom as a controlled setting for guided connections to be established. The Socratic Method can be seen as fulfilling this ideology, and advances in technology allow instructors to bring this controlled setting to more people than ever before.

The Socratic Method cannot be replaced, but it can be refined and supported by each of the leading theories of education. Behaviorist and cognitivist approaches already appear in supplemental law school exercises, and slight alterations to these will ensure student success. Constructivism and connectivism materialize through the Socratic Method as it is already utilized. Humanist considerations in legal theory ensure that the law is just. By reconsidering legal education as a whole, and not simply relying on traditional approaches, the law school classroom can create lawyers with greater cognizance, efficacy, and zeal than ever before.

\section{REFERENCE}

- Adom, D., Yeboah, A., \& Ankrah , K. (2016). Constructivism Philosophical Paradigm: Implication for Research, Teaching, and Learning. Global Journal of Arts Humanities and Social Sciences, 1-9.

- $\quad$ Akintunde, A. (2018). Towards A Socratic Method of Teaching in the Nigerian Classrooms. Current Educational Research, 1(5), 58-67.

- Al Dahdouh , A. (2019). Individual Learning Experience in Connectivist Environment: A Qualitative Sequence Analysis. International Journal of Research in Education and Science, 488-509.

- Al Dahdouh, A. A. (2020). Emotions Among Students Engaging in Connectivist Learning Experiences. International Review of Research in Open and Distributed Learning, 99-117.

- Al-Jarrah, T. M., Mansor, N., Talafhah, R. H., \& Al-Jarrah, J. M. (2018). The Application of Metacognition, Cognitivism, and Constructivism in Teaching Writing Skills. European Journal of Foreign Language Teaching ,199-213. 
- Altorf, H. M. (2019). Dialogue and discussion: Reflections on a Socratic method. Arts and Humanities in Higher Education, 60-75.

- Banks, J. A. (2016). Cultural Diversity and Education (6th ed.). New York: Taylor \& Francis.

- Bodenheimer, E., Oakley, J. B., \& Love, J. C. (2004). An Introcudtion to the Anglo-American Legal System (4th ed.). St. Paul, USA: West Publishing Co.

- Boghossian, P. (2013). Behaviorism, Constructivism, and Socratic Pedagogy. Educational Philosophy and Theory, 713-722.

- Chetwin, M., \& Edgar, C. (1999). Legal Education in the Technology Revolution: The Evolutionary nature of computer-assisted learning. Legal Education Review, 163-177.

- Corbin, L., \& Bugden, L. (2018). Online Teaching: The Importance of Pedagogy, Place and Presence in Legal Education. Legal Education Review, 1-21.

- Dennison, D. (2011). Integrating Justice Through Course Design: A Report from Uganda Christian University Faculty of Law. IJM Student Learning \& Global Justice Conference (pp. 1-15). Washington, D.C.: Council for Christian Colleges and Universities .

- Donahoe, D. R., \& Ross, J. (2020). Lighting the Fires of Learning in Law School: Implementing ABA Standard 314 by Incorporating Effective Formative Assessment Techniques Across the Curriculum. University of Pittsburgh Law Review, $1-46$.

- Downes, S. (2020). Recent Work in Connectivism. European Journal of Open, Distance and ELearning, 113-132.

- Emma, J. (2018). Transforming legal education through emotions. Legal Studies, 450-479.

- Endarto, B., Alam, A. S., \& Abadi, S. (2019). Curriculum Development in the Field of Law: Facing the New Era of Industrial Revolution 4.0. Journal of Physics: Conference Series, 1-6.

- Ertmer, P. A., \& Newby, T. J. (2013). Behaviorism, cognitivism, constructivism: Comparing critical features from an instructional design perspective. Performance Improvement Quarterly, 43-71.

- Fox, E., \& Riconscente, M. (2008). Metacognition and self-regulation in James, Piaget, and Vygotsky. Educational Psychology Review, 373-389.

- Garrison, M. J. (2018). Resurgent Behaviorism and the Rise of Neoliberal Schooling. In K. J. Saltman, \& A. J. Means, The Wiley Handbook of Global Educational Reform (pp. 323-349). New York: John Wiley \& Sons, Inc.

- Hawkins-León, C. G. (1998). The Socratic Method-Problem Method Dichotomy: The Debate Over Teaching Method Continues. Bringham Young University Education and Law Journal, 1(2), 1-18.

- Higueras-Herbada, A., de Paz, C., Travieso, D., Ibáñez-Gijón, J., \& Jacobs, D. M. (2019). The direct learning theory: a naturalistic approach to learning for the post-cognitivist era. Adaptive Behavior, 389-403.

- Jacobs, H. H. (2010). Curriculum 21: Essential Education for a Changing World. Alexandria, USA: Association for Supervision and Curriculum Development.

- Javadi, Y., \& Tahmasbi, M. (2020). Application of Humanism Teaching Theory and Humanistic Approach to Education in Coursebooks. Theory and Practice in Language Studies, 40-48.

- Kaufman, M. J. (2017). Social Justice and the American Law School Today: Since We Are Made for Love. Seattle University Law Review, 11891287.

- Kizito, R. N. (2016). Connectivism in Learning Activity Design: Implications for PedagogicallyBased Technology Adoption in African Higher Education Contexts. International Review of Research in Open and Distributed Learning, 19-39.

- Kleeger, J. (2019). Implementing a Meaningful \& Effective Legal Education Reform . Journal of Commonwealth Law and Legal Education, 1-25.

- Kleeger, J. (2019). Legal Education ReformUnmasking the Multidisciplinary Constitution of Law. Journal of Multidisciplinary Research, 65-86.

- Kohn, A. (2006). The Trouble with Rubrics. English Journal, 12-13.

- Kouwenhoven, W. (2009). Competence-based curriculum development in higher education: some African experiences. In A. Lazinica, \& C. Tavares Calafate, Technology Education and Development (pp. 126-146). London: IntechOpen.

- Lefrançois, G. R. (2020). Theories of Human Learning (7th ed.). Cambridge: Cambridge.

- Maharg , P. (2016). The Periclean Plumber: Simulation and Legal Education. In B. Bergmans , Yearbook of Legal Education (pp. 187-212). Berlin: Wissenschafts-Verlag.

- Manji , A., \& Harrington, J. (2019). 'Africa Needs Many Lawyers Trained for the Need of their Peoples': Struggles over Legal Education in Kwame Nkrumah's Ghana. American Journal of Legal History, 149-177.

- Mattar, J. (2018). Constructivism and connectivism in education technology: Active, situated, authentic, experiential, and anchored learning. Revista Iberoamericana de Educación a Distancia, 201-217.

- Motallebinejad, A., Hatami, J., \& Farda, H. (2019). Toward More Effective Legal Education for Adolescents: Systematic or Constructivist Instructional Design Models? Journal of Constructivist Psychology, 1-16.

- Northrup, D. (2013). Africa's Discovery of Europe. Oxford: Oxford University Press.

- Noyes, J. K. (2002). Humanism, embodied knowledge, and postcolonial theory. In $\mathrm{M}$. 
Albrecht, Postcolonialism Cross-Examined (pp. 51-64). New York: Routledge.

- Nyatuame, P. N. (2019). The 'Evaluation Triangle' in Theatre-For-Development Education in Ghana. Journal of African Arts \& Culture, 1-24.

- Olivares, R. A., \& Lemberger, N. (2002). Identifying and Applying the Communicative and the Constructivist Approaches to Facilitate Transfer of Knowledge in the Bilingual Classroom. International Journal of Bilingual Education and Bilingualism, 72-83.

- Ovens, M., \& Jonker, D. (2014). The development of a fully online interdisciplinary module within the College of Law : a case study. Acta Criminologica : African Journal of Criminology \& Victimology, Special Edition 2, 1-13.

- Ramrathan, L. (2019). Centering Humanism Within the Milieu of Sustained Student Protest for Social Justice in Higher Education Within South Africa. Higher Education and Hope, 241-257.

- Sahin, M. (2012). Pros and Cons of Connectivism as a Learning Theory. International Journal of Physical and Social Sciences, 2(4), 437-454.

- Sánchez Cabrero, R., \& Costa Román, Ó. (2018). Psychopedagogical Predecessors of Connectivism as a New Paradigm of Learning. International Journal of Educational Excellence, 29-45.

- Schneider, J. (2013). Remembrance of Things Past: A History of the Socratic Method in the United States. Curriculum Inquiry 43:5 (2013), 43(5), 613640.

- Smith, M. (2019). Integrating technology in contemporary legal education. The Law Teacher, 113.

- Sokoloff, W. W. (2020). Against the Socratic Method. In C. Palgrave Macmillan, Political Science Pedagogy. Critical Political Theory and Radical Practice (pp. 51-68). Edinburg, USA: University of Texas Rio Grande Valley.

- Soudien, C. (2019). The significance of new humanism for education and development. Prospects, 309-320.

- Tyler, R. W. (1949). Basic Principles of Curriculum and Instruction. Chicago: The University of Chicago Press.

- Wilson, S. M., \& Peterson, P. L. (2006). Theories of learning and teaching: What do they mean for educators? Atlanta: National Education Association. 